\title{
Virus-like particles associated with marine mussel mortalities in New Zealand
}

\author{
J. B. Jones ${ }^{1, *}$, P. D. Scotti ${ }^{2}$, S. C. Dearing ${ }^{2}$, B. Wesney ${ }^{1}$ \\ ${ }^{1}$ MAF Fisheries Research Centre, Ministry of Agriculture and Fisheries, PO Box 297, Wellington, New Zealand \\ ${ }^{2}$ The Horticulture and Food Research Institute of New Zealand Ltd, Private Bag 92 169, Auckland, New Zealand
}

\begin{abstract}
Green-lip mussel Perna canaliculus spat (15 to $30 \mathrm{~mm}$ length) in the outer Marlborough Sounds, New Zealand, suffered 50 to $100 \%$ mortality during January to April 1994 (summer/autumn) following thinning and reseeding of the mussel lines by farmers. Adult mussel mortalities of 2 to $5 \%$ continued from February to early May 1994. Histological examination showed extensive haemocytosis and multifocal liquefaction necrosis of interstitial cells, basal cells and digestive tubule epithelial cells. Sloughed pyknotic or karyolytic digestive tubule epithelial cells formed characteristic rounded granular bodies 10 to $15 \mu \mathrm{m}$ diameter both in digestive tubules and free in lesions. No viral inclusion bodies were observed. Ultrastructural examination showed highly modified rough endoplasmic reticulum associated with small, 25 to $45 \mathrm{~nm}$ diameter, electron-dense uncoated virus-like particles. Identical cell damage and virus-like particles were subsequently found in monbund adult ( 75 to $110 \mathrm{~mm}$ length) P. canaliculus and stunted ( 25 to $47 \mathrm{~mm}$ length) subtidal Mytilus galloprovincialis from the same area. Following purfication of extracts of the moribund spat by isopycnic centrifugation in $\mathrm{CsCl}$, large numbers of $25 \mathrm{~nm}$ diameter, unenveloped, virus particles were seen by electron microscopy. These particles had a density of $1.364 \mathrm{~g} \mathrm{~cm}^{-3}$ A broad band at a density expected for enveloped particles (1.21 to $1.24 \mathrm{~g} \mathrm{~cm}$ ) was also observed but contained few virus-like particles. Cell damage and mussel mortalities are thus likely due to a small unenveloped virus.
\end{abstract}

KEY WORDS: Bivalve - Perna Mytilus - Endoplasmic reticulum - Histology $\cdot$ Ultrastructure $\cdot$ Virus

\section{INTRODUCTION}

The aquaculture of green-lip mussels Perna canaliculus is an important industry in New Zealand. Production is centred on the Marlborough Sounds (Fig. 1) and in 1993 reached $47000 \mathrm{t}$, worth in excess of NZ\$ 55 million free on board (F.O.B.). Though there have been no recorded disease outbreaks in New Zealand mussel farms there has been an ongoing problem with high post-settlement spat mortalities. Environmental factors, resulting in starvation, have been blamed for the losses (Jenkins et al. 1985, Hayden 1987, Buchanan 1994).

In January and February 1994 (summer) mussel farmers in the outer Marlborough Sounds carried out

\footnotetext{
- Present address: Fisheries Department of Western Australia, c/o Animal Health Laboratory, 3 Baron-Hay Court, South Perth, Western Australia 6151.

E-mail:brianj@aidpo.agric.wa.gov.au
}

routine thinning and reseeding of the mussel lines. Approximately 2 wk post reseeding, farmers examining mussel lines noticed that much of the reseeded spat were dead or moribund. Mortalities continued into March 1994 when samples of spat and adult mussels from affected farms were sent to the Ministry of Agriculture and Fisheries (MAF) for examination. By that time, farms in the affected area had lost between 50 and $100 \%$ of their reseeded spat but no pattern could be discerned in mortalities either between or within affected farms (P. Lupi, NZ Mussel Industry Council, pers. comm.). Mortalities ceased by early May, but occurred again 2 wk post reseeding in November 1994. Histological examination confirmed spat were not starving though they presented extensive haemocytosis and multifocal liquefaction necrosis of interstitial cells, basal cells and digestive tubule epithelial cells. Sloughed pyknotic or karyolytic digestive tubule epithelial cells formed characteristic rounded granular bodies 10 to $15 \mu \mathrm{m}$ diameter both in digestive tubules 


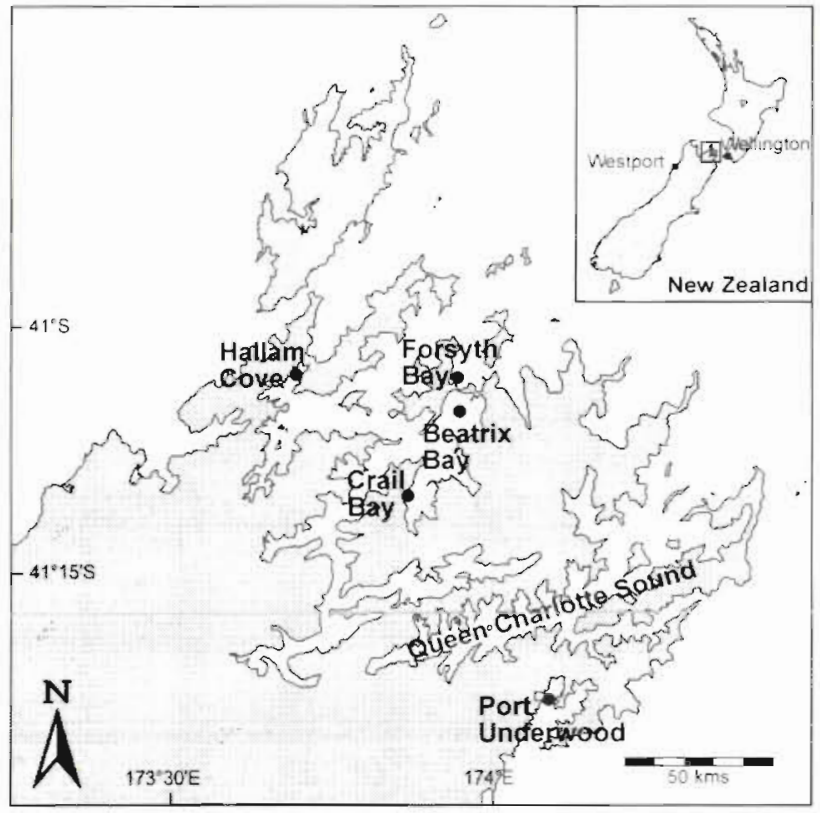

Fig. 1. Location of the affected areas in Marlborough Sounds. Insert: position of Marlborough Sounds in relation to sampling sites at Westport and Wellington

and free in lesions. Ultrastructural examination revealed that cell damage was associated with the presence of small virus-like particles. This paper describes the histology and ultrastructural pathology associated with these particles and the isolation of large numbers of virus particles from these affected mussels.

\section{MATERIAIS AND METHODS}

Between 10 and 30 spat (15 to $30 \mathrm{~mm}$ in length) of Perna canaliculus were examined from individual. mussel ropes in Hallam Cove $(\mathrm{n}=30)$, Forsythe Bay $(\mathrm{n}=70)$ and Crail Bay ( $\mathrm{n}=10$ ) (Marlborough Sounds; Fig. 1) on 1 March 1994. Adult mussels (75 to $110 \mathrm{~mm}$ in length) were obtained from the same sites on 9 March 1994 ( $n=298$ ), and a further sample of dying mussels (56 to $109 \mathrm{~mm}$ ) from Port Underwood on 1 May 1994 ( $n=49$ ). Stunted but otherwise apparently healthy blue mussels Mytilus galloprovincialis (25 to $47 \mathrm{~mm}$ in length) were obtained from the inlet pipe at the NZ Oysters Hatchery in Queen Charlotte Sound, Marlborough. Sounds, on 27 June $1994(n=7)$. Intertidal adult $M$. galloprovincialis (35 to $56 \mathrm{~mm}$ in length) ( $n=10$ ) were obtained on 2 June 1994 from Evans Bay, Wellington Harbour, for use as a control.

A set of 7 green-lip Perna canaliculus and 7 blue Mytilus galloprovincialis mussel slides from the MAF Fisheries parasitology slide coljection, made from moribund shellfish collected at Westport in March
1990, were also re-examined. The mussels had been sampled from intertidal rocks near Westport on the west coast of South Island, New Zealand. The mussels were reported to be gaping and extensive patches of recently dead mussels, identified by traces of necrotic tissue within the valves, were present. Electron microscope grids prepared in 1991 from green-lip mussel spat collected in the Marlborough Sounds, probably at Beatrix Bay, in April 1991 were also re-examined.

For light microscopy, a slice of mussel tissue was taken through the mantle-digestive gland, fixed in Davidson's fluid, embedded in wax, sectioned at $3 \mu \mathrm{m}$, and stained with haematoxylin and eosin or Feulgen stain. For electron microscopy, small pieces of digestive diverticulum were fixed in $2.5 \%$ glutaraldehyde in filtered $(0.22 \mu \mathrm{m})$ seawater for 1 to $2 \mathrm{~h}$, post-tixed in $1 \% \mathrm{OsO}_{4}$ (in $0.1 \mathrm{M}$ sodium cacodylate buffer) for $1 \mathrm{~h}$, washed, dehydrated in ascending ( 50 to $100 \%$ ) ethanol series, followed by two 10 min changes in propylene oxide, and embedded in epoxy resin. Sections were stained with $5 \%$ uranyl acetate for $10 \mathrm{~min}, 5 \%$ lead citrate for $5 \mathrm{~min}$, and examined with a Philips 420 ST electron microscope.

For partial purification of virus, whole 15 to $25 \mathrm{~mm}$ spat were macerated in a commercial mincer in $0.02 \mathrm{M}$ phosphate buffer, $\mathrm{pH} 7.2$, containing $0.85 \% \mathrm{NaCl}$ phosphate-buffered saline (PBS). Following filtration through muslin and a low speed spin to remove debris, polyethylene glycol (MW 6000, BDH, Poole, England) was added to $10 \%(\mathrm{w} / \mathrm{v})$ and $\mathrm{NaCl}$ to $0.5 \mathrm{M}$. After standing for $1 \mathrm{~h}$, the extract was spun at low speed and the resultant pellet resuspended in PBS to approximately one-quarter of the original volume. After 2 lowspeed clarification spins, the supernatant was centrifuged at $52000 \times g$ for 220 min in a Beckman Type 30 rotor. The pellets were resuspended in a total volume of $10 \mathrm{ml}$ of PBS, given a low-speed clarification spin, and centrifuged at $71000 \times g$ for $60 \mathrm{~min}$ in a halffilled tube in a Beckman Type 40 rotor. The pellet was resuspended in $1 \mathrm{ml} 0.1 \mathrm{M}$ phosphate buffer, $\mathrm{pH} 7.2$.

Isopycnic centrifugation in $\mathrm{CsCl}$ was performed in $0.1 \mathrm{M}$ phosphate buffer, pH 7.2 and the density of the virus band estimated as described by Scotti (1985). The gradients were fractionated by gently inserting a metal cannula to the bottom of the tube and then collecting equal volume fractions using a peristaltic pump (LKB 2120 Varioperpex II, LKB Produkter, Sweden). Absorbance was monitored at a wavelength of $254 \mathrm{~nm}$ using an LKB flat-bed potentiometer linked to an LKB UVICORD. Fractions containing the virus were removed, diluted in $0.1 \mathrm{M}$ phosphate buffer and centrifuged at $71000 \times g$ for $90 \mathrm{~min}$ in a half-filled tube in a Beckman Type 40 rotor. The virus pellet was resuspended in a small volume of phosphate buffer and examined by electron microscopy with a Jem 1200EXIl (JEOL, Japan) after staining with $2 \%$ phosphotungstic acid, pH 7.0 . 


\section{RESULTS}

\section{Histology}

Examination of sectioned Perna canaliculus spat from Marlborough Sounds revealed extensive haemocyte infiltration of the digestive gland connective tissue and the occurrence of multifocal progressive liquefaction necrosis of the digestive gland interstitial cells and the digestive tubule basal and epithelial cells. No fibrous reaction to the abscesses was observed. The periacinar zone of affected digestive diverticula presented acute cell swelling with cytolysis and sloughing of epithelial cells into the lumen. Sloughed cells were pyknotic or karyolytic and formed characteristic rounded granular bodies 10 to $15 \mu \mathrm{m}$ diameter within the lumen of the digestive tubules and in lesions (Figs 2 \& 3). No viral inclusion bodies were seen and Feulgen staınıng showed no abnormal DNA accumulations

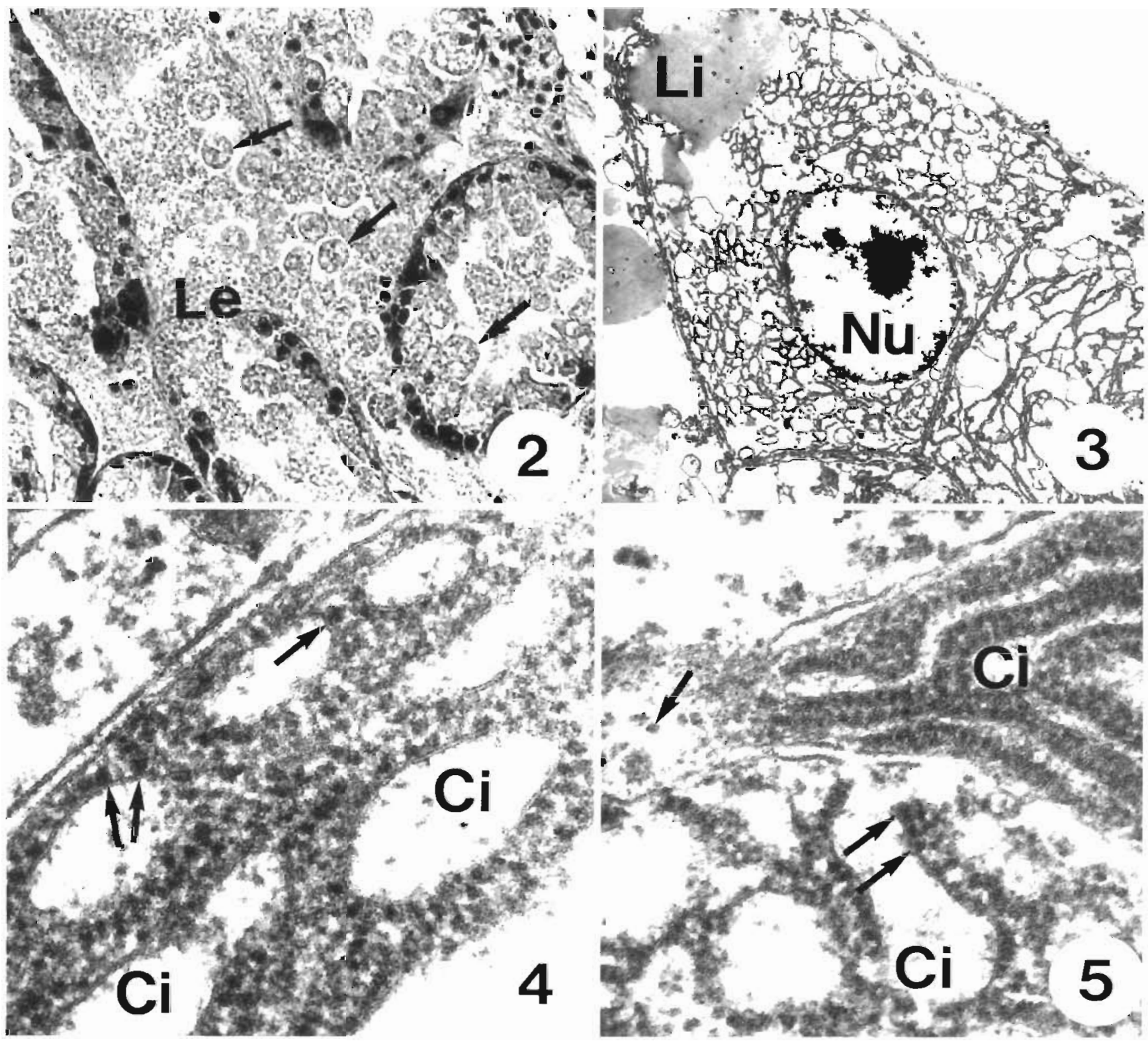

Figs. 2 to 5. Perna canaliculus. Fiq. 2. Digestıve divertıcula showing lesıons (Le) and sloughed digestıve divertıcula epithelıal cells (arrows). H\&E, $\times 395$. Fig. 3. Basophilic cell remains showing chromatin aggregation in nucleus (Nu), lipid droplets (Li) and proliferation of endoplasmic reticulum (ER) throughout the cell $\times 58000$. Fig. 4 Basophilıc cell Detail of prolıferatıng ER showing ribosome-like bodies, denser staining virus-like particles (arrows) and swollen cisternae $(\mathrm{Cl}) \times 150000$ Fig. 5 . Basophilıc cell showing swelling and rupture of the ER cisternae $(\mathrm{Cl})$ (lower right). Virus-like particles occur in the cytoplasm and along the membrane fragments (arrows) $\times 89000$ 
Sections through the digestive gland of both Perna canaliculus and Mrtilus galloprovincialıs from Westport presented the same lesions with associated 10 to $15 \mu \mathrm{m}$ rounded sloughed cells and haemocytic inf.ltrate which were characteristic of the moribund Marlborough Sounds mussels.

\section{Ultrastructural examination}

Ultrastructural examination of Perna canalıculus spat showed that the 10 to $15 \mu \mathrm{m}$ diameter cells were sloughed necrotıc digestive cells containing a pyknotic or karyolytıc nucleus and large numbers of lipid droplets, empty vacuoles and residual bodies. Within the digestive gland epithelal layer, all 3 cell types [digestive cells and basophulıc cells (types I and II of Thompson et al. 1974)] were affected Cells presented clusters of membranebound and free poiyribosomes often in the vicinity of the nucleus. The cisternae of the endoplasmic reticulum (ER) was dilated, but without disaggregation of ribosomes, compressing the cytoplasm so that cells were highly vacuolar in appearance. This was particularly evident in

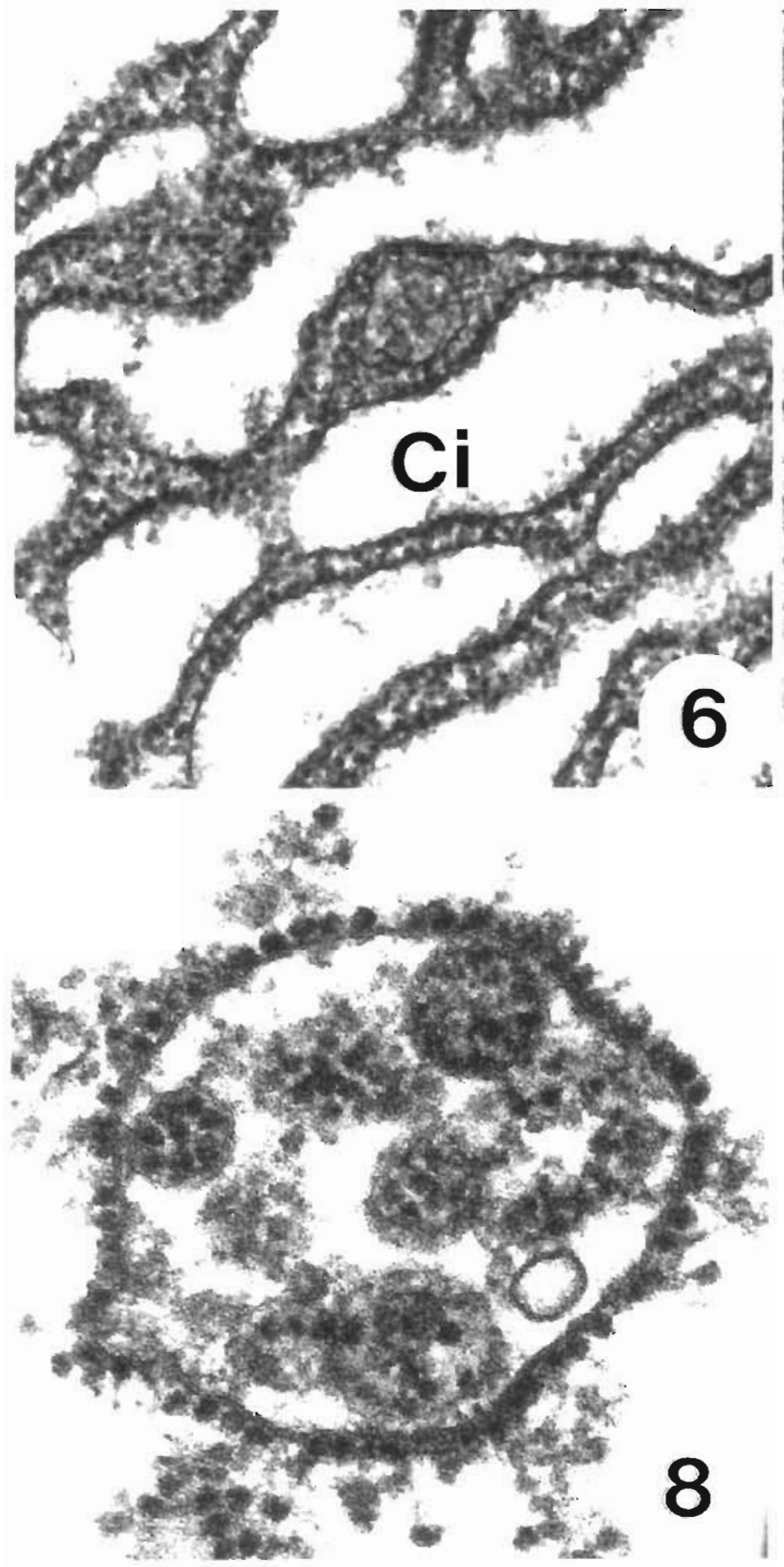

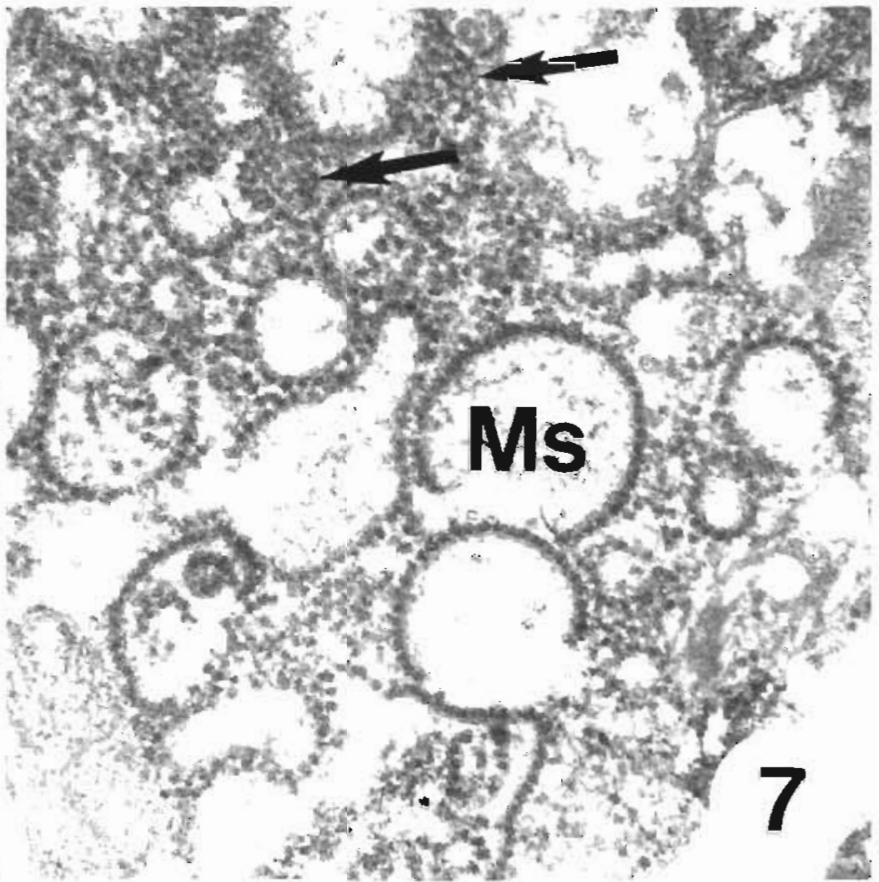

Figs 6 to 8. Perna canaliculus. Fig. 6. Digestive cell showing degeneration of $E R$ and swelling and rupture of the cisternae (C) with compression of cytoplasmic contents; $\times 72500$ Fig 7 Basophilic cell showing disruption of the ER and formation of microsome precursors (Ms). Virus-like particles occur in the cytoplasm (arrows); $\times 62$ 000. Fig. 8. Digestive cell showing detall of microsome containing virus-like particles 
basophilic cells (Fig. 4). The membranes around the endoplasmic cisternae were thickly lined with ribosomes and virus-like particles (25 to $35 \mathrm{~nm}$ diameter, $n=100$ ), the latter distinguished from ribosomes by the darker staining, larger size, and often solitary occurrence (Figs. $5 \& 6$ ). The mitochondrial matrix was dense. Nuclear chromatin was condensed, the nuclear membrane and the cell membrane were still intact (Fig. 3).

In acute phase, the ER had split, leaving strings of ribosomes attached to a curled portion of double membrane, or rings of membrane resembling microsomes (Fig. 7). Double-membranebound vesicles 0.7 to $3 \mu \mathrm{m}$ diameter were common and extensive areas of $\alpha$-glycogen accumulation occurred in the cytoplasm. In cells with extensive microsome formation, clusters of viruslike particles occurred within the microsome cisternae, apparently by

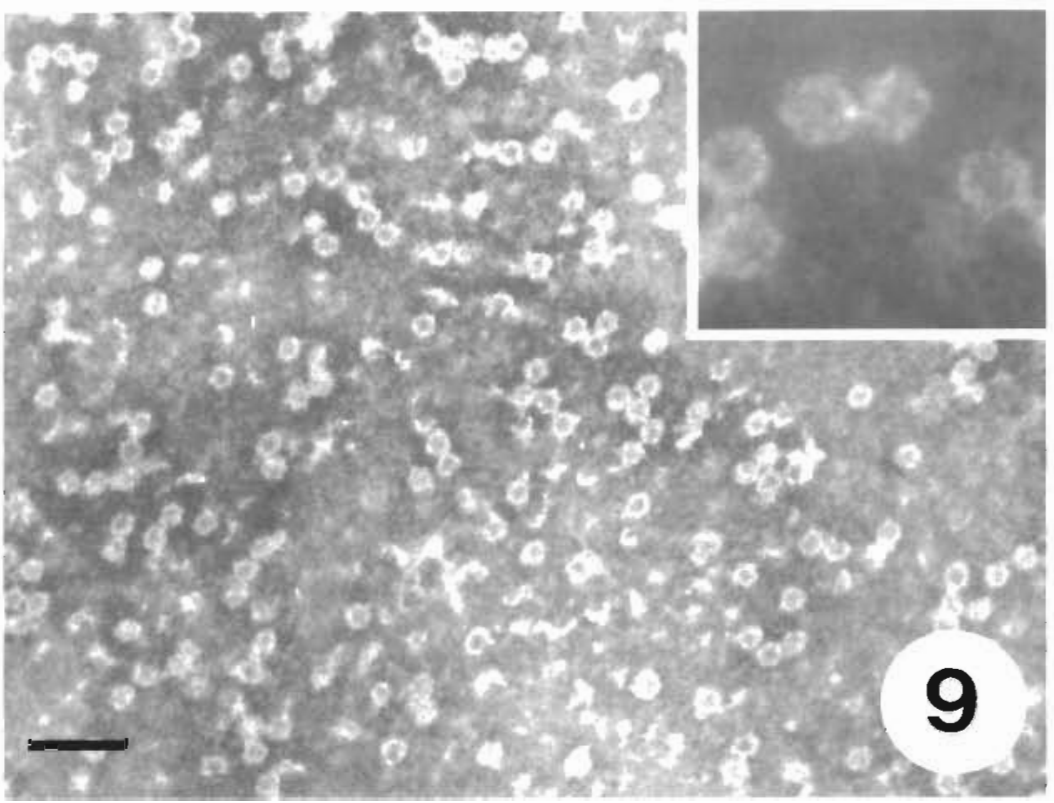

Fig. 9. Perna canaliculus. Virus particles isolated by isopycnic gradient centrifugation in $\mathrm{CsCl}$ from moribund spat. Scale bar $=100 \mathrm{~nm}$; inset shows particles at higher magnification

budding through the double membrane fragment (Fig. 7), so that clusters of particles were within a double membrane (Fig. 8). Their function is unclear. No occlusion bodies or paracrystalline arrays were found.

The same pathology and associated virus-like particles were found in the 1991 sample of Perna canaliculus spat from Beatrix Bay and in Mytilus galloprovincialis from the oyster hatchery pipe in Queen Charlotte Sound. The M. galloprovincialis material from Wellington Harbour showed normal cell ultrastructure, and was used, as a control.

In purified extracts of spat, a light-scattering band was seen after isopycnic centrifugation in $\mathrm{CsCl}$. The UV-absorbing peak was estimated to be at $1.364 \mathrm{~g}$ $\mathrm{cm}^{-3}$. Electron microscope (EM) examination of the peak fraction revealed numerous unenveloped virus particles about $25 \mathrm{~nm}$ in diameter (Fig. 9). A broad light-scattering band was also observed at densities from 1.21 to $1.24 \mathrm{~g} \mathrm{~cm}^{-3}$ but no enveloped or unenveloped particles were seen in subsequent EM examination.

\section{DISCUSSION}

The histology and ultrastructure of the digestive gland of Mytilus galloprovincialis and Perna canaliculus is typical of the digestive gland described for several species of bivalve mollusc (Pal 1971, 1972, Thompson et al. 1974, Mix et al. 1979, Henry 1984a, b, Henry et al. 1991). At the ultrastructural level, 3 types of cell have been identified, a non-flagellate basophilic cell, a flagellate basophilic cell (basophilic cells types I and II of Thompson et al. 1974) and a digestive cell. The effects on Mytilus digestive gland of starvation and stress (Thompson et al. 1974), toxic hydrocarbons (Lowe et al. 1981, Moore \& Clarke 1982, Nott \& Moore 1987) and toxic algae (Parry et al. 1989) have been described but the pathology observed in the New Zealand $P$. canaliculus and $M$. galloprovincialis samples was not consistent with those studies. Environmental causes for the observed mortalities were therefore discounted.

The histopathology seen in affected mussels is similar to the haemocyte infiltration and connective tissue necrosis seen in the digestive diverticulum of Ostrea edulis infected with Tellina virus (an IPN-like reovirus) (Hill \& Alderman 1979). Iridovirus-infected Crassostrea angulata develop large globular cells 30 to $40 \mu \mathrm{m}$ diameter in necrotic gill tissues. These hypertrophied cells were first considered to be a stage in the life cycle of a protozoan and were named Thanatostrea polymorpha (Comps \& Duthoit 1976, 1979, Comps 1978). The exfoliated digestive cells we observed in Perna canaliculus also had the general appearance of a protozoan (Fig. 2).

There is 1 record of virus-associated mortalities in New Zealand shellfish. Hine et al. (1992) described a herpes-like virus associated with hatchery-reared larval Pacific oysters Crassostrea gigas. An apparently identical herpes-like virus also occurs in hatcheryreared Tiostrea lutaria spat raised at elevated temper- 
atures ( $J$ B. Jones pers. obs.). No evidence of herpeslike virus was seen in the mussel samples examined in this study.

The cellular changes observed here show a pattern of proliferation of ribosomes along the ER and around the nuclear envelope. Single electron-dense ribosomelike particles are common in the cytoplasm, yet ribosomes rarely occur as single particles but are aggregated into polyribosomes of varying sizes (Fenner 1968). The association of electron-dense particles with the rough ER, which swells forming large vacuoles before rupturing and forming microsomes, is consistent with a viral infection. Changes to, and proliferation of, membranous structures resembling ER and resulting from small RNA virus infection have been reported by Daies (1965), Kim \& Boatman (196\%), Merkow et al. (1970), Patrizi \& Middelkamp (1970), Yudin \& Clark (1979) and Couch (1989). The strong positive staining with lead citrate is also characteristic of RNA (Hayat 1975)

Mix et al. (1979) studied hypertrophied Mytilus edulis granulocytes from Oregon, USA, which characterised a putative neoplastic disease. They reported that the large cells (15 $\mathrm{\mu m}$ diameter) present throughout the vesicular connective tissue were associated with pleomorphic, polymorphic nuclei, altered Golgi, mitochondrial crystalline inclusions and abundant free 'ribosomes'. Lowe \& Moore (1978) described similar large cells from $M$. edulis at Plymouth, UK. Mix et al. (1979) concluded that though the cells possessed many properties characteristic of certain malignant vertebrate cells, the cause of the presumptive neoplastic disorder was unknown. A picorna-like virus has been found associated with granulocytomas in Danish $M$. edulis. The $27 \mathrm{~nm}$ virus particles form paracrystalline arrays and the mitochondria of affected areas often contain non-viral associated crystalline inclusions (Rasmussen 1986, Bower \& Figueras 1989). The absence of mitochondrial inclusions and arrays and the characteristic proliferation of ER suggests that the New Zealand virus may be different from that reported in Denmark.

The 1994 mortalities occurred approximately 2 wk after reseeding of the mussel lines in January 1994 and again about 2 wk after reseeding in November 1994 , a process which causes considerable stress for the mussel spat, leaving a permanent growth 'check' on the shell (J. B. Jones pers. obs.). Mortalities among older mussels were less noticeable, affecting 2 to $5 \%$ of mussels from the outer Sounds, and occurred later than for spat, in March through to early May. This is a period when the condition factor of Perna canaliculus in the Sounds is high although water temperatures have started to fall from a February (summer) high of Ca $19^{\circ} \mathrm{C}$ to an August low of ca $10^{\circ} \mathrm{C}$ (Jenkins et al. 1985). Mortalities among larger mussels would prob- ably have gone unreported were it not for the loss of much of the reseeded spat in 1994. It is also possible that the onset of the mortalities $2 \mathrm{wk}$ after rough handling is due to the accumulation of lactate in mussels following stress-induced anaerobic respiration. Some small RNA viruses are known to be associated with lactate pathways and the production of large numbers of double membrane vesicles (Plagemann \& Moenig 1992).

The presence of the virus in Sounds mussels in January to April, the histopathology suggestive of the virus in Westport mussels from April 1990, and the heavy mortalities of local Sounds summer spatfall since the early 1980s (Jenkins et al. 1985) suggest that the virus has been present in the Sounds for many years and has escaped detection due to its small size and lack of paracrystalline arrays. Large numbers of virus particles were only seen after concentrating and purifying extracts made from $300 \mathrm{~g}$ of whole spat.

Similar histological and ultrastructural changes were seen in local scallops Pecten novaezelandiae, which have suffered periodic mass mortalities of unknown aetiology since at least the $1960 \mathrm{~s}$ (J. B. Jones pers. obs.). We therefore suggest that this group of viruses may prove to be common shellfish pathogens and that the neoplastic granulocytes reported by Lowe \& Moore (1978) and Mix et al. (1979) deserve further ultrastructural examination. Further work on the detailed properties and occurrence of this virus is under way.

Acknowledgements. We thank Paul Lupi of the NZ Mussel Industry Council for bringing the problem to our attention. Drs P. M. Hine and D. Lightner for their encouragement and helpful suggestions as to the identity of the virus; A. Blacklock and $\mathrm{Mr} \mathrm{J}$. Ingerson for assistance with the figures; the staff at the Victoria University of Wellington electron microscope facility for assistance in preparing the EM grids; and Paul Sutherland of HortResearch for technical help with electron microscopy

\section{LITERATURE CITED}

Bower SM, Figueras AJ (1989) Infectious diseases of mussels World Aquacult 20(4):89-93

Buchanan S (1994) The spat trap. Removing the risk from spat production. Seafood NZ 2(7):54-55

Comps M (1978) Évolution des recherches et études récentes en pathologie des huîtres. Oceanol Acta 1:255-262

Comps M. Duthoit JL (1976) Infection virale associée à la 'maladie des branchies' de l'huitre portugaise Crassostrea angulata Lmk. Cr Hebd Séance Acad Sci Paris (Sér D) 283:1595-1596

Comps M, Duthoit JL (1979) Infections virales chez les huîtres Crassostrea angulata Lmk. et Crassostrea gigas Th. Haliotis 8:301-307

Couch JA (1989) The membranous labyrinth in baculovirusinfected crustacean cells: possible roles in viral reproduction. Dis Aquat Org 7:39-53 
Dales S (1965) Replication of animal viruses as studied by electron microscopy. Am J Med 38:699-715

Fenner F (1968) The biology of animal viruses, Vol 1, Molecular and cellular biology. Academic Press, New York

Hayat MA (1975) Positive staining for electron microscopy. Van Nostrand Reinhold Co., New York

Hayden B (1987) Marlborough Sounds mussel spat resource. Catch 14(10): 15-16

Henry M (1984a) Ultrastructure des tubules digestifs d'un mollusque bivalve marin, la palourde Ruditapes decussatus L., en métabolisme de routine. 1. La cellule digest.uve. Vie Mar 6:7-14

Henry M (1984b) Ultrastructure des tubules digestifs d'un mollusque bivalve marin, la palourde Ruditapes decussatus L., en métabolısme de routine. II. La cellule sécrétrice. Vie Mar 6:17-24

Henry M, Boucaud-Camou E, Lefort Y (1991) Functional micro-anatomy of the digestive gland of the scallop Pecten maximus (L.). Aquat Living Resour 4:191-202

Hill BJ, Alderman DJ (1979) Observations on the experimental infection of Ostrea edulis with two molluscan viruses. Haliotis 8:297-299

Hine PM, Wesney B, Hay BE (1992) Herpesvirus associated with mortalities among hatchery reared larval Pacific oysters Crassostrea gigas. Dis Aquat Org 12:135-142

Jenkins RJ, Meredyth-Young J, Waugh GD (1985) Mussel cultivation in the Marlborough Sounds (New Zealand) revised 2nd edn. New Zealand Fishing Industry Board, Wellington

Kin KSW, Boatman ES (1967) Electron microscopy of monkey kidney cell cultures infected with rubella virus. J Virol $1: 205-214$

Lowe DM, Moore MN (1978) Cytology and quantitative cytochemistry of a proliferative atypical hemocytic condition In Mytilus edulis (Bivalvia, Mollusca). J Nat Cancer Inst 60: 1455-1459

Lowe DM, Moore MN, Clark KR (1981) Effects of oil on digestive cells in mussels: quantitative alterations in cellular and lysosomal structure. Aquat Taxicol 1:213-226

Merkow LP, Slifkin M, Pardo M, Rapoza NP (1970) Pathogenesis of oncogenic simian adenoviruses. VII. The origin

Responsible Subject Editor: A. K. Sparks, Seattle,

Washington, USA of annulate lamellae in LLC-MK2 cells infected with SV30. J Ultrastruct Res 30:344-353

Mix MC, Hawkes JW, Sparks AK (1979) Observations on the ultrastructure of large cells associated with putative neoplastic disorders of mussels, Mytilus edulis, from Yaquina Bay, Oregon. J lnvertebr Pathol 34:41-56

Moore MN, Clarke KR (1982) Use of microstereology and quantitative cytochemistry to determine the effects of crude oil-derived aromatic hydrocarbons on lysosomal structure and function in a marine bivalve molluse. Mytilus edulis. Histochem J 14:713-718

Nott A, Moore MN (1987) Effects of polycyclic aromatic hydrocarbons on molluscan lysosomes and endoplasmic reticulum. Histochem J 19:357-368

Pal SG (1971) The fine structure of the digestive tubules of Mya arenaria L. 1. Basiphil cell. Proc Malac Soc Lond 39:303-309

Pal SG (1972) The fine structure of the digestive tubules of Mya arenaria L. II. Digestive cell. Proc Malac Soc Lond 40:161-170

Parry GD, Langdon JS, Huisman JM (1989) Toxic effects of a bloom of the diatom Rhizolenia chunii on shellfish in Port Phillip Bay, southeastern Australia. Mar Biol 102:25-41

Patrizi G, Middelkamp JN (1970) Development and changes of annulate lamellae complexes in Rubella virus-infected RK-13 cells. J Ultrastruct Res 31:407-423

Plagemann PGW, Moenig V (1992) Lactate dehydrogenaseelevating virus, equine arteritis virus, and simean hemorrhagic fever virus: a new group of positive-strand RNA viruses. Adv Virus Res 41:99-192

Rasmussen LPD (1986) Virus associated granulocytomas in the marine mussel Mytlus edulis, from three sites in Denmark. J Invertebr Pathol 48:117-123

Scotti PD (1985) The estimation of virus density in isopycnic cesium chloride gradients. J Virol Meth 12:149-160

Thompson RJ, Ratcliff NA, Bayne BL (1974) Effects of starvation on structure and function of the digestive gland of the mussel (Mytilus edulis L.). J Mar Biol Ass UK 54:699-712

Yudin AI, Clark WH Jr (1979) A description of rhabdoviruslike particles in the mandibular gland of the blue crab, Callinectes sapidus. J Invertebr Pathol 33:133-147

Manuscript first received: October 26, 1994

Revised version accepted: July 13,1995

(publication delayed because of oversight by Subject Editor) 